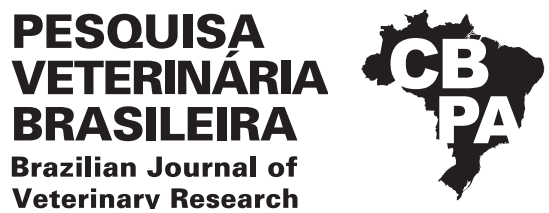

Pesq. Vet. Bras. 40(7):514-518, July 2020 DOI: $10.1590 / 1678-5150-P V B-6625$

Original Article

Veterinarv Research

ISSN 0100-736X (Print)

Livestock Diseases

ISSN 1678-5150 (Online)

\title{
DNA extraction methods for molecular detection of Eimeria spp. in cattle and sheep ${ }^{1}$
}

\author{
Caroline Z. Reginato ${ }^{2}$, Patrícia Bräunig ${ }^{3 *}$ (D), Luiza P. Portella ${ }^{2}$ (D), \\ Ana Paula G. Mortari ${ }^{2}$, Camila E. Minuzzi ${ }^{2}$, Luis Antonio Sangioni ${ }^{3}$ \\ and Fernanda S.F. Vogel $^{3}$
}

\begin{abstract}
Reginato C.Z., Bräunig P., Portella L.P., Mortari A.P.G., Minuzzi C.E., Sangioni L.A. \& Vogel F.S.F. 2020. DNA extraction methods for molecular detection of Eimeria spp. in cattle and sheep. Pesquisa Veterinária Brasileira 40(7):514-518. Universidade Federal de Santa Maria, Av. Roraima 1000, Cidade Universitária, Camobi, Santa Maria, RS 97105-900, Brazil. E-mail: pbraunig@gmail.com

Molecular detection of Eimeria species in fecal samples can be useful for experimental and diagnostic purposes. However, the parasite quantity presence in feces and the oocyst wall are an obstacle in DNA extraction protocols. Therefore, adequate sampling and effective disruption of the oocysts are essential to improve the accuracy of DNA detection by PCR. The aims of this study were to evaluate the suitability of six protocols for DNA extraction from Eimeria spp. present in bovine and sheep. Twenty pools of fecal samples from cattle (10 pools) and sheep (10 pools) were distributed to six DNA extraction protocols: commercial kit, commercial kit with modification, DNAzol, cetyl-trimethyl ammonium bromide (CTAB), glass beads and commercial kit for fecal samples. Fecal samples were submitted to DNA extraction and PCR. Among the protocols tested, CTAB was determined to be most suitable for DNA extraction from oocysts ( $90 \%$ of DNA detection by PCR); DNAzol and CTAB resulted in higher DNA detection from bovine samples (80\%). CTAB and commercial kit with modification improved PCR detection of Eimeria spp. in sheep samples, with positive amplification of DNA in all tested samples.
\end{abstract}

INDEX TERMS: DNA extraction, molecular detection, Eimeria spp., cattle, sheep, PCR, fecal samples.

\begin{abstract}
RESUMO.- [Métodos de extração de DNA para detecção molecular de Eimeria spp. em bovinos e ovinos.] A detecção molecular de espécies de Eimeria em amostras fecais pode ser útil para fins experimentais e de diagnóstico. No entanto, a quantidade de parasitas nas fezes e a parede do oocisto são um obstáculo nos protocolos de extração de DNA. Portanto, uma amostragem adequada e a ruptura efetiva dos oocistos são essenciais para melhorar a precisão da detecção de DNA por PCR. Os objetivos deste estudo foram avaliar seis protocolos para extração de DNA de Eimeria spp. em amostras de bovinos e ovinos. Foram distribuídos 20 grupos de amostras fecais de bovinos (10 grupos) e ovinos (10 grupos) em seis protocolos de extração de DNA: kit comercial, kit comercial
\end{abstract}

\footnotetext{
${ }^{1}$ Received on April 23, 2020.

Accepted for publication on May 16, 2020.

${ }^{2}$ Universidade Federal de Santa Maria, Av. Roraima 1000, Cidade Universitária, Camobi, Santa Maria, RS 97105-900, Brazil.

${ }^{3}$ Departamento de Medicina Veterinária Preventiva, Universidade Federal de Santa Maria, Av. Roraima 1000, Cidade Universitária, Camobi, Santa Maria, RS 97105-900, Brazil. *Corresponding author: pbraunig@gmail.com
}

com modificação, DNAzol, brometo de cetil-trimetil amônio (CTAB), pérolas de vidro e kit comercial para amostras fecais. As amostras fecais foram submetidas à extração de DNA e PCR. Entre os protocolos testados, CTAB foi considerado o mais adequado para extração de DNA de oocistos $(90 \%$ de detecção de DNA por PCR); DNAzol e CTAB resultaram em maior detecção de DNA em amostras de bovinos (80\%). CTAB e kit comercial com modificação melhoraram a detecção por PCR de Eimeria spp. em amostras de ovinos, amplificação positiva de DNA em todas as amostras testadas.

TERMOS DE INDEXAÇÃO: Extração de DNA, detecção molecular, Eimeria, bovinos, ovinos, DNA, PCR, amostras fecais.

\section{INTRODUCTION}

Coccidiosis is an infection caused by protozoa of the genus Eimeria of great economic importance because of the losses due to clinical disease (diarrhea) and subclinical infections (poor weight gain) (Chartier \& Paraud 2012). Eimeria spp. develop in the small and large intestines of the hosts, is specie 
specific and several species of Eimeria were identified infecting cattle and sheep affecting mainly young animals (Daugschies \& Najdrowski 2005, Chartier \& Paraud 2012).

Eimeria bovis and Eimeria zuernii are most commonly pathogenic species in calves worldwide causing morbidity and mortality by disturbing intestinal absorption and often associated with diarrheic feces (Daugschies \& Najdrowski 2005). The most pathogenic Eimeria spp. in sheep are Eimeria ovinoidalis which develops in the large intestine and Eimeria crandallis (Chartier \& Paraud 2012).

Subclinical form of coccidiosis is difficult to diagnose and low rates of fatality are associated with this disease, however Eimeria spp. infection negatively impact ruminants mainly on decreasing growth and increasing susceptibility to diseases (Vieira etal. 1999). Diagnosis of eimeriosis infections should be based on epidemiological aspects, clinical signs and laboratory test results, including: light microscopy traditional fecal examination and molecular techniques, especially polymerase chain reaction (PCR) (Carvalho et al. 2011, Chartier \& Paraud 2012).

Molecular assays for the diagnosis of Eimeria spp. infection are known to have greatly improved through more effective DNA extraction techniques and more sensitive PCR techniques for identifying protozoa (Kawahara et al. 2010, Carvalho et al. 2011, Malek \& Kuraa 2018). Previous studies have revealed that one of the steps that can influence PCR results is the DNA extraction methods used (Zhao et al. 2001, Kaya et al. 2007, Tang et al. 2018).

DNA extraction process is essential for the success of the PCR technique, favoring a more sensitive and specific diagnosis. Thus, the present work aimed to compare different DNA extraction methods of Eimeria spp. oocysts from sheep and cattle.

\section{MATERIALS AND METHODS}

\section{Samples and parasitological examination}

Cattle and sheep feces were collected directly from the rectum using sterile gloves and placed in clean plastic bottles. The fecal samples were transferred under refrigeration to the laboratory and kept at $4^{\circ} \mathrm{C}$ until processing.

Eggs and oocysts per gram of feces (EPG) counting was performed using a modified McMaster technique, with a sensitivity of $50 \mathrm{EPG}$. Samples that had an oocysts count $\geq 500$ were selected for both cattle and sheep.

\section{Eimeria spp. oocysts examination}

Positive fecal samples (oocysts count $\geq 500$ ) were separated according animal species (cattle or sheep) and 10 pools of feces from each experimental group was formed. Therefore, 2 to $4 \mathrm{~g}$ from a pool of feces were homogenized, dissolved in distilled water and filtered through sieves $(60 \mu \mathrm{m})$. Several washes were performed according Hoffman et al. (1934) and when the supernatant became clear, flotation centrifugation technique (Ueno \& Gonçalves 1998) was used to separate and concentrate the oocysts. Finally, the recovered oocysts were stored in $2 \%$ potassium dichromate solution, quantified in Newbauer chamber and stored at $4^{\circ} \mathrm{C}$ until DNA extraction.

\section{DNA extraction protocols}

Each sample was twice washed with distilled water, centrifuged for $10 \mathrm{~min}$ at $14,000 \times \mathrm{g}$ to remove the potassium dichromate solution. The pellet with a number of approximately 5000 oocysts/pool was subsequently submitted to DNA extraction protocols.
Protocol 1 (commercial kit). Genomic DNA was extracted using a commercial kit (Wizard Genomic DNA Purification Kit, Promega, USA) according to manufacturer's instructions. Briefly, $600 \mu \mathrm{L}$ of Nuclei Lysis Solution was added to the pellet of oocysts, homogenized, and incubated at $65^{\circ} \mathrm{C}$ for $30 \mathrm{~min}$. After incubation, $3 \mu \mathrm{L}$ of RNase Solution was added, incubated for $30 \mathrm{~min}$ at $37^{\circ} \mathrm{C}$, followed by addition of $200 \mu \mathrm{L}$ of Protein Precipitation Solution, vortexed, chilled on ice for $5 \mathrm{~min}$, and centrifuged at $13000 \times \mathrm{g}$ for $4 \mathrm{~min}$. The supernatant was transferred to a fresh tube containing $600 \mu \mathrm{L}$ of isopropanol, mixed and centrifuged at $13000 \times \mathrm{g}$ for 1 min. After centrifugation, the supernatant was removed, and $600 \mu \mathrm{L}$ of $70 \%$ ethanol was added to the pellet and centrifuged at the conditions described above. The ethanol was aspirated, the pellet was air-dried, and the DNA rehydrated in $50 \mu \mathrm{L}$ of DNA Rehydration Solution for 1 hour at $65^{\circ} \mathrm{C}$.

Protocol 2 (commercial kit with modification). Genomic DNA was extracted using the commercial kit (Wizard Genomic DNA Purification Kit, Promega, USA) with a modification: after RNase addition, the lysis step was carried out at $55^{\circ} \mathrm{C}$ and kept overnight (16h) (adapted from Moré et al. 2011).

Protocol 3 (DNAzol reagent). Genomic DNA was extracted using a specific reagent (DNAzol Reagent, Invitrogen, USA) according to manufacturer's instructions. Briefly, $1 \mathrm{ml}$ DNAzol was added to the pellet of oocysts followed by homogenization and centrifugation ( 5 $\min$ at $10,000 \times \mathrm{g}$ at $4^{\circ} \mathrm{C}$ ). Each resulting viscous supernatant was transferred to a new tube. Genomic DNA precipitation was carried out by adding $0.5 \mathrm{ml}$ of cold $100 \%$ ethanol, homogenized, incubated for $3 \mathrm{~min}$ at room temperature and centrifuged at the conditions described above. Finally, genomic DNA was washed with $1 \mathrm{ml}$ of cold $75 \%$ ethanol and centrifuged (same conditions described above), after centrifugation, supernatant was discarded and the resulting pellet suspended in $50 \mu \mathrm{L}$ of MilliQ water.

Protocol 4 (CTAB). The pellets of oocysts were incubated for 10 min with $100 \mu \mathrm{L}$ of lysis buffer (lysozyme $10 \mathrm{mg} / \mathrm{ml}$, SDS $10 \%$ and proteinase $\mathrm{K} 10 \mathrm{mg} / \mathrm{ml}$ ) at $37^{\circ} \mathrm{C}$. This was followed by addition of $100 \mu \mathrm{L}$ cetyl-trimethyl ammonium bromide (CTAB) and $100 \mu \mathrm{L}$ of $5 \mathrm{M} \mathrm{NaCl}$ into the solution and incubation at $65^{\circ} \mathrm{C}$ for $10 \mathrm{~min}$. Finally, genomic DNA was isolated from the lysate by the phenol-chloroform method (Sambrook \& Russel 2001), precipitated by cold ethanol, and solubilized in $50 \mu \mathrm{L}$ MilliQ water.

Protocol 5 (glass beads). To perform the protocol with glass beads, in to the oocysts pellet was added $100 \mu \mathrm{L}$ of STES buffer $(0.2$ $\mathrm{M}$ Tris- $\mathrm{HCl}, 0.1 \%$ SDS (w/v), EDTA $0.01 \mathrm{M}, \mathrm{pH} 7.6$ ), $50 \mu \mathrm{L}$ of $0.5 \mathrm{~mm}$ glass beads and $100 \mu \mathrm{L}$ phenol-chloroform, vortexed for 1 minute. After that, the solution was centrifuged at $13000 \mathrm{~g}$ for $5 \mathrm{~min}$, the supernatant was collected and transferred to a new, sterile tube and precipitated by adding cold $2 \mathrm{~V}$ (volume) absolute ethanol and $0.1 \mathrm{~V} 5 \mathrm{M} \mathrm{NaCl}$. After 30 minutes, the solution was centrifuged again at $1200 \mathrm{~g}$ for $10 \mathrm{~min}$. The pellet was washed twice with $70 \%$ ethanol and after that, DNA was eluted in $50 \mu \mathrm{L}$ MilliQ water.

Protocol 6 (commercial kit for fecal samples). A specific kit for extraction of genomic DNA from fecal samples was also used according to manufacturer's instructions (PureLink ${ }^{\circledR}$ Genomic DNA Mini Kits). Basically, kit consists in specific digestion buffers, purification column for DNA, washing buffers and an elution buffer, resulting in a final volume of $50 \mu \mathrm{L}$.

The concentration and quality of DNA extracted from each sample were analyzed using spectrophotometer NanoDrop 1000 (absorbance of 260/280nm ratio for purity evaluation) (Thermo Scientific, USA). After that, the DNA samples were stored at $-20^{\circ} \mathrm{C}$ until use in PCR. 


\section{PCR and electrophoretic analysis}

DNA extracted by the different protocols described above was submitted to the polymerase chain reaction (PCR) under the same conditions, using a set of primers (F: 5'-GCA AAA GTC GTA ACA CGG TTT CCG -3' and R: 5'-CTG CAA TTC ACA ATG CGT ATC GC-3') (Malek \& Kuraa 2018) for amplification of a 348-546 bp fragment from the internal transcribed spacer 1 (ITS-1). Each PCR was performed in a total volume of $25 \mu \mathrm{L}$, containing $10 \mathrm{X}$ buffer (Promega, USA); $10 \mathrm{mM}$ dNTPs (Ludwig Biotec, Brazil); $50 \mu \mathrm{m}$ of each primer (Sigma-Aldrich, Brazil); 1U Taq DNA polymerase (Promega, USA); and 50ng of DNA as template. DNA extracted from a pool of sporulated oocysts using the commercial kit was used as positive control and MilliQ water was used as negative control. The PCR was carried out using a T100 thermal cycler (BioRad, USA) under the following conditions: 30 seconds at $94^{\circ} \mathrm{C}$ for the initial hot denaturation step, followed by 35 cycles of 10 seconds at $94^{\circ} \mathrm{C}, 20$ seconds at $55^{\circ} \mathrm{C}, 20$ seconds at $72^{\circ} \mathrm{C}$, and a final extension step of $2 \mathrm{~min}$ at $72^{\circ} \mathrm{C}$. The PCR products were visualized by UV illumination after electrophoresis at $1 \%$ agarose gel stained with Gel Red Nucleic Acid Stain (Biotium, USA).

\section{Statistical analysis}

Software IBM SPSS Statistics 23 was used to calculate the kappa coefficient to estimate the concordance rate among the extraction protocols. The frequencies of positive and negative samples obtained using each DNA extraction protocol were compared by the Fisher's exact test at a $99 \%$ confidence level.

\section{RESULTS}

All the extraction protocols have resulted in DNA amplification by PCR (Table 1). CTAB (Protocol 4) showed better results with regard to DNA extraction from pools of oocysts (Table 1), with the Eimeria spp DNA detected from $90 \%$ (18/20) of the samples. This frequency was higher than the $70 \%(14 / 20)$ detection obtained using either the commercial kit for fecal samples (Protocol 6) or DNAzol (Protocol 3). Commercial kit (Protocol 1) showed a lower detection frequency (45, 9/20). Kappa coefficient was obtained using Protocol 4 as standard therefore, Protocols 1 (commercial kit), 3 (DNAzol) and 6 (commercial kit for fecal samples) demonstrated slight concordance (kappa 0.167 and 0.118) with Protocol 4 (CTAB). However, Protocol 5 (glass beads) showed moderate (kappa 0.48) and Protocol 2 (commercial kit with modification) fair concordance (kappa 0.318) with CTAB (Protocol 4).

In cattle fecal samples, Protocols 3 (DNAzol) and 4 (CTAB) showed better results (80\%), 8/10 samples were positive

Table 1. PCR results from DNA extracted by six extraction protocols from cattle and sheep isolated oocysts

\begin{tabular}{|c|c|c|c|c|c|c|}
\hline \multirow{3}{*}{ Sample } & \multicolumn{6}{|c|}{ PCR results from the six DNA extraction protocols tested } \\
\hline & $* \mathrm{P} 1$ & $\mathrm{P} 2$ & P3 & $\mathrm{P} 4$ & P5 & P6 \\
\hline & Kit & Kit with modification & DNAzol & CTAB & Glass beads & Kit for fecal samples \\
\hline$* * \mathrm{C} 1$ & + & + & + & + & + & + \\
\hline $\mathrm{C} 2$ & + & + & + & + & + & + \\
\hline $\mathrm{C} 3$ & + & + & + & + & + & + \\
\hline $\mathrm{C} 4$ & - & + & + & + & + & + \\
\hline $\mathrm{C} 5$ & - & + & + & + & - & + \\
\hline C6 & - & + & + & + & - & + \\
\hline $\mathrm{C} 7$ & - & + & + & + & - & - \\
\hline C8 & - & - & + & + & - & - \\
\hline C9 & - & - & - & - & - & - \\
\hline C10 & - & - & - & - & - & - \\
\hline $\begin{array}{l}\text { Total bovine } \\
\text { samples }\end{array}$ & $3 / 10$ & $7 / 10$ & $8 / 10$ & $8 / 10$ & $4 / 10$ & $6 / 10$ \\
\hline$* * * \mathrm{~S} 1$ & + & + & + & + & + & + \\
\hline $\mathrm{S} 2$ & + & + & + & + & + & + \\
\hline S3 & + & + & + & + & + & + \\
\hline S4 & + & + & + & + & + & + \\
\hline S5 & + & + & + & + & + & + \\
\hline S6 & + & + & + & + & + & + \\
\hline S7 & - & + & - & + & + & + \\
\hline S8 & - & + & - & + & + & + \\
\hline S9 & - & + & - & + & - & - \\
\hline S10 & - & + & - & + & - & - \\
\hline Total sheep samples & $6 / 10$ & $10 / 10$ & $6 / 10$ & $10 / 10$ & $8 / 10$ & $8 / 10$ \\
\hline Total fecal samples & $9 / 20$ & $17 / 20$ & $14 / 20$ & $18 / 20$ & $12 / 20$ & $14 / 20$ \\
\hline
\end{tabular}

${ }^{*} \mathrm{P}=$ protocol, ${ }^{* *} \mathrm{C}=$ pool of cattle fecal samples, ${ }^{* * *} \mathrm{~S}=$ pool of sheep fecal samples. 
in PCR when these protocols were used for DNA extraction. Interestingly, in fecal samples from sheep, Protocols 2 (commercial kit with modification) and 4 (CTAB) resulted in $100 \%$ (10/10) of DNA amplification.

\section{DISCUSSION}

Coccidiosis causes economic losses in livestock as a result of decrease in feed efficiency which leads to slow weight gain and increased predisposition to other diseases (Malek \& Kuraa 2018). Therefore, accurate diagnosis of coccidiosis is important to promote animal health and consequently to reduce losses. There is different diagnosis of Eimeria spp. using different methods with different specificity and sensitivity (Carvalho et al. 2011) and PCR which is known as a specific and sensitive method of diagnosis showed a high frequency of Eimeria spp. detection in the present study, reinforcing that coccidia are widely distributed across bovine and ovine.

Haug et al. (2007) observed that there is a variation in the detection of each Eimeria spp., depending on the number of oocysts used and the technique adopted for DNA extraction. However, Fernandez et al. (2003) identified Eimeria spp. in samples containing from two to eight oocysts proving that PCR correctly detect and discriminate species from small quantities of oocysts. Therefore, PCR is much sensitive compared to oocyst-counting using McMaster's method that can quantify as much as 100 oocysts in $1 \mathrm{~g}$ of faeces (Kawahara et al. 2010).

In field samples, many factors may interfere in the success of diagnosis by PCR, especially the presence of contamination (Carvalho et al. 2011). According to Haug et al. (2007) the DNA extraction process in stool samples is influenced by the formation of inhibitors of Taq DNA polymerase that affect the reaction. We compared results obtained from six DNA extraction methodologies and found that CTAB was more efficient. Glass bead grinding is based on frequent physical contact between oocysts to break the wall, but the frequency of contact decreases with the small number of oocysts, resulting in less oocyst breakage (Tang et al. 2018). In addition, the amount of DNA from ruptured sporozoites that remains adhered to the glass beads and/or the container wall also reduces the total yield of DNA (Zhao et al. 2001, Tang et al. 2018). In contrast, Protocol 3 (DNAzol) and 4 (CTAB) are performed in microtubes resulting in minimal loss of DNA. In addition, since the commercial DNA kit can adsorb substances that could degrade DNA and inhibit downstream enzymatic reactions, it also dramatically reduced PCR sensitivity (Kumar et al. 2014, Tang et al. 2018).

Eimeria's oocyst walls contain two or more shell layers (Scholtyseck et al.1971, Hammond \& Long 1973, Duszynski et al. 1981, Long 1982). The thick and elastic outer skeletal layer is made of a chitin-like material (Wilson \& Fairbairn 1961) and contains quinone-tanned proteins that can be dissolved in hypochlorite (Hammond \& Long 1973). Some DNA extraction protocols use sodium hypochlorite to promote oocysts lysis (Carvalho et al. 2011, Tang et al. 2018) and although none of the six protocols tested used hypochlorite, they showed to be efficient in oocysts lysis resulting in positive PCRs.

Results demonstrated that the PCR assay targeting the ITS-1 region of Eimeria spp. in cattle and sheep can be used for detection of this parasite. The ITS- 1 regions are flexible corresponding with species variation, as compared with whole rRNA genes, showing a pattern of low intra-specific and high inter-specific variations in the DNA sequence (Kawahara et al. 2010). Accurate identification of Eimeria spp. is important not only for the diagnosis of disease and management of subclinical infections but also for epidemiological studies (Sun et al. 2009, Lee et al. 2010). PCR facilitates the detection of parasites including at subclinical levels, at concentrations that may be missed by routine microscopy (Tang et al. 2018) and in this study we tested six DNA extraction protocols in which oocysts were ruptured, DNA released and extracted in concentration and purity appropriately for PCR detection.

\section{CONCLUSIONS}

All the extraction protocols tested have promoted DNA releasing from Eimeria spp. oocysts.

CTAB protocol showed to be better in DNA extraction from pools of Eimeria oocysts. Therefore, CTAB should be considered as DNA extraction method in molecular studies involving Eimeria oocysts from sheep and cattle.

Conflict of interest.- The authors declare that they have no conflict of interest.

\section{REFERENCES}

Carvalho F.S., Wenceslau A.A., Teixeira M., Carneiro J.A.M., Melo A.D.B. \& Albuquerque G.R. 2011. Diagnosis of Eimeria species using traditional and molecular methods in field studies. Vet. Parasitol. 176(2/3):95-100. <http://dx.doi.org/10.1016/j.vetpar.2010.11.015> <PMid:21167646>

Chartier C. \& Paraud C. 2012. Coccidiosis due to Eimeria in sheep and goats, a review. Small Ruminant Res. 103(1):84-92. <http://dx.doi.org/10.1016/j. smallrumres.2011.10.022>

Daugschies A. \& Najdrowski M. 2005. Eimeriosis in cattle: current understanding. J. Vet. Med. B 52(10):417-427. <http://dx.doi.org/10.1111/j.1439-0450.2005.00894.x> <PMid:16364016>

Duszynski D.W., Speer C.A., Chobotar B. \& Marchiondo A.A. 1981. Finestructure of the oocyst wall and excystation of Eimeria procyonis from the American raccoon (Procyon lotor). Z. Parasitenkd., Berlin, 65(2):131-136. <http://dx.doi.org/10.1007/BF00929178><PMid:7281900>

Fernandez S., Pagotto A.H., Furtado M.M., Katsuyama A.M., Madeira A.M. \& Gruber A. 2003. A multiplex PCR assay for the simultaneous detection and discrimination of the seven Eimeria species that infect domestic fowl. Parasitology 127(Pt 4):317-325. <http://dx.doi.org/10.1017/ s0031182003003883><PMid:14636018>

Hammond D.M. \& Long P.L. 1973. The Coccidia. University Park Press, Baltimore, p.151-154.

Haug A., Thebo P. \& Mattsson J.G. 2007. A simplified protocol for molecular identification of Eimeria species in field samples. Vet. Parasitol. 146(1/2):3545. <http://dx.doi.org/10.1016/j.vetpar.2006.12.015><PMid:17386979>

Hoffman W.A., Pons J.A. \& Janer J.L. 1934. The sedimentation concentration method in Schistosomiasis mansoni. Puerto Rico J. Publ. Health Trop. Med. 9:283-289.

Kawahara F., Zhang G., Mingala C.N., Tamura Y., Koiwa M., Onuma M. \& Nunoya T. 2010. Genetic analysis and development of species-specific PCR assays based on ITS-1 region of rRNA in bovine Eimeria parasites. Vet. Parasitol. 174(1/2):49-57. <http://dx.doi.org/10.1016/j.vetpar.2010.08.001> $<$ PMid:20817404>

Kaya G., Dale C., Maudlin I. \& Morgan K. 2007. A novel procedure for total nucleic acid extraction from small numbers of Eimeria species oocysts. Turkiye Parazitoloji Dergisi 31(3):180-183. <PMid:17918054>

Kumar S., Garg R., Moftah A., Clark E.L., Macdonald S.E., Chaudhry A.S., Sparagano O., Banerjee P.S., Kundu K., Tomley F.M. \& Blake D.P. 2014. An optimised protocol for molecular identification of Eimeria from 
chickens. Vet Parasitol. 199(1/2):24-31. <http://dx.doi.org/10.1016/j. vetpar.2013.09.026><PMid:24138724>

Lee B.H., Kim W.H., Jeong J., Yoo J., Know Y., Jung B.Y., Know J.H., Lillehoj H.S. \& Min W. 2010. Prevalence and cross-immunity of Eimeria species on Korean chicken farms. J. Vet. Med. Sci. 72(8):985-989. <http://dx.doi. org/10.1292/jvms.09-0517><PMid:20234110>

Long P.L. 1982. The Biology of the Coccidia. University Park Press, Baltimore, p.144-152.

Malek S.S. \& Kuraa H.M. 2018. Detection and identification of Eimeria species in naturally infected calves at assuit governorate. Zagazig Vet. J. 46(1):6069. <http://dx.doi.org/10.21608/ZVJZ.2018.7624>

Moré G., Abrahamovich P., Jurado S., Bacigalupe D., Marin J.C., Rambeaud M., Venturini L. \& Venturini M.C. 2011. Prevalence of Sarcocystis spp. in Argentinean cattle. Vet. Parasitol. 177(1/2):162-165. <http://dx.doi. org/10.1016/j.vetpar.2010.11.036><PMid:21168276>

Sambrook J. \& Russell D.W. 2001. Molecular Cloning: a laboratory manual. 3rd ed. Cold Spring Harbor Laboratory Press, Cold Spring Harbor, New York, p.A1.26.

Scholtyseck E., Mehlhorn H. \& Hammond D.M. 1971. Fine structure of macrogametes and oocysts of Coccidia and related organisms. Z. Parasitenkd., Berlin, 37(1):1-43. <http://dx.doi.org/10.1007/BF00259543><PMid:4327670>
Sun X.M., Pang W., Jia T., Yan W.C., He G., Hao L.L., Bentué M. \& Suo X. 2009. Prevalence of Eimeria species in broilers with subclinical signs from fifty farms. Avian Dis. 53(2):301-305. <http://dx.doi.org/10.1637/8379061708-Resnote.1><PMid:19630240>

Tang X., Huang G., Liu X., El-Ashram S., Tao G., Lu C., Suo J. \& Suo X. 2018. An optimized DNA extraction method for molecular identification of coccidian species. Parasitol. Res. 117(3):655-664. <http://dx.doi.org/10.1007/ s00436-017-5683-8><PMid:29396674>

Ueno H. \& Gonçalves P.C. 1998. Manual para Diagnóstico das Helmintoses de Ruminantes. Embrapa Gado de Corte, Campo Grande. 143p.

Vieira L.S., Cavalcante A.C.R. \& Ximenes L.J.F. 1999. Infection with Eimeria species in hair sheep reared in Sobral, Ceará State, Brazil. Revta. Med. Vet. 150(6):547-550.

Wilson P.A. \& Fairbairn D. 1961. Biochemistry of sporulation in oocysts of E. acervulina. J. Protozool. 8(4):410-416. <http://dx.doi. $\operatorname{org} / 10.1111 / \mathrm{j} .1550-7408.1961 . t b 01236 . x>$

Zhao X., Duszynski D.W. \& Loker E.S. 2001. A simple method of DNA extraction for Eimeria species. J. Microbiol. Methods 44(2):131-137. <http://dx.doi. org/10.1016/s0167-7012(00)00249-9><PMid:11165342> 